\title{
Evaluation of baroclinic effects on mean water levels in Guanabara Bay
}

\section{Avaliação de efeitos baroclínicos em níveis médios de água na Baía de Guanabara}

\author{
Verônica Silveira de Andrade ${ }^{1}$ (D), Paulo Cesar Colonna Rosman ${ }^{1}$ (D), José Paulo Soares de Azevedo AiD $^{1}$ \\ ${ }^{1}$ Universidade Federal do Rio de Janeiro, Rio de Janeiro, RJ, Brasil
}

E-mails: veronicaandrade@coc.ufrj.br(VSA),pccrosman@ufrj.br (PCCR), zepaulo@coc.ufrj.br (JPSA)

Received: July 04, 2018 - Revised: July 21, 2019 - Accepted: September 04, 2019

\begin{abstract}
This study analyzes hydrodynamic aspects of the Guabanara Bay estuarine system, which is in the southern coast of the state of Rio de Janeiro, Brazil. Hydrodynamic circulation patterns were characterized, with and without the influence of baroclinic pressure gradients due to water density differences. Typical summer and winter scenarios are considered. The evaluation adopted computational simulations of hydrodynamic circulation, using models from the environmental hydrodynamic base system, entitled SisBaHiA. The simulations indicate that by disregarding baroclinic effects in the pressure gradients, the mean water levels in the Guanabara Bay are underestimated up to 5 centimeters, depending on the region and season of year. However, the hydrodynamic circulation patterns with or without baroclinic pressure gradients are very similar, as shown by the circulation patterns maps in different tidal phases.
\end{abstract}

Keywords: Guanabara Bay estuarine system; Computational modeling; Estuarine hydrodynamics; Salinity baroclinic pressure gradient.

\section{RESUMO}

Este trabalho analisa aspectos hidrodinâmicos do sistema estuarino da Baía de Guanabara, localizado na costa sul do estado do Rio de Janeiro, Brasil. Padrões de circulação hidrodinâmica foram caracterizados, com e sem influência de gradientes de pressão baroclínicos devido a diferenças de densidade da água, para cenários típicos de verão e de inverno. A avaliação foi realizada por meio de simulações computacionais de circulação hidrodinâmica, com a utilização de modelos do Sistema Base de Hidrodinâmica ambiental, entitulado SisBaHiA. As modelagens indicam que a não inclusão de efeitos baroclínicos nos gradientes de pressão subestima níveis médifnefos de água na Baía de Guanabara em valores de até 5 centímetros dependendo da região e da época do ano. Entretanto, os padrões de circulação hidrodinâmica com ou sem gradientes de pressão baroclínicos são muito similares, como mostram os mapas de circulação em diferentes fases de maré.

Palavras-chave: Sistema estuarino da Baía de Guanabara; Modelagem computacional; Hidrodinâmica estuarina; Salinidade; Gradiente de pressão baroclínico. 


\section{INTRODUCTION}

An estuary is a coastal body of water with free connection to the sea, within which there is a measurable mixture of freshwater from the hydrographic basin with seawater and extending upstream up to the tidal influence limit (DYER, 1997). An estuarine system constitutes a set of estuaries that flow into a larger system, like a bay or a lagoon, such as Guanabara Bay (GB), into which several rivers outflow.

These environments are extremely dynamic and have large amounts of available nutrients, enhancing a rich biodiversity. Changes in response to natural forces are constant, as well as their vulnerability arising from anthropic activities. (MIRANDA et al., 2017).

The Guanabara Bay is in the metropolitan region of Rio de Janeiro. It has a maximum extension of about $28 \mathrm{~km}$ in the direction $\mathrm{E}-\mathrm{W}$ and of little more than $30 \mathrm{~km}$ in the direction $\mathrm{N}-\mathrm{S}$, covering an area of approximately $450 \mathrm{~km}^{2}$ including several islands. The set of watersheds that drain to the bay covers an area of more than $4000 \mathrm{~km}^{2}$, with diversified topography comprising mountains, flat areas of lowlands and sandbanks, mangroves and beaches (COELHO, 2007; PSAM, 2014). There are dozens of rivers and streams that flow into $G B$, the top 16 of which are considered in this study. Although so many rivers flow into GB, the average tidal flow in GB's mouth outweighs about 200 times the average river inflow, which explains the almost homogeneous density of the water column in the bay. The mixing ratio, i.e., the ratio between freshwater volume per tidal cycle and the average spring tide prism is less than 0.05 . That indicates a strong tendency to a vertically homogeneous estuarine system (DYER, 1997).

This estuarine system has enormous environmental and economic importance for the region. However, GB faces several pollution problems. Nowadays, domestic sewage represents one of the largest polluting agents of the rivers and of GB itself, with several other sources of pollution, such as industrial and ship-source pollution.

As highlighted by Roversi, Rosman and Harari (2016a), this reinforces the importance of understanding the hydrodynamic circulation of an estuarine system, and the behavior of constituents present in it, in order to enlarge the framework of tools and information available to substantiate and guide action strategies for management policies and environmental projects.

The hydrodynamic circulation in a vertically homogeneous estuarine system responds to two mechanisms that generate pressure gradients: the barotropic gradient, due to the differences in elevation caused by the tides, and the horizontal gradient of baroclinic pressure generated by density differences. Usually, in estuaries, the effects of barotropic gradients are one to two orders of magnitude greater than those of baroclinic gradients. A simple analysis of the relative magnitude of the terms shows the fact. For this reason, the baroclinic effects in vertically homogeneous estuaries are often disregarded.

In view of the above, this study aims to analyze the influence of the horizontal baroclinic pressure gradient on the variation of the mean water levels and the circulation pattern of the estuarine system of Guanabara Bay, considering typical scenarios of summer and winter.

\section{MATERIAL AND METHODS}

The mean sea level is a magnitude that is influenced by several forces, such as astronomical tides, meteorological effects, atmospheric pressure, winds, precipitation, evaporation, salinity, temperature, among other variables (KALIL, 1999).

In this study, the mean water level (MWL) in each location is considered as the statistical average of the levels recorded throughout the simulation, considering full tidal cycles in a lunar month. Because the models record results at regular time intervals, for example, hourly, this average coincides with the arithmetic average of the water levels in each analyzed point. In order to analyze the influence of baroclinic pressure gradients in Guanabara Bay, in all hydrodynamic and transport models, the same environmental forces were introduced, except for the role of salinity that alters the water density. Four hydrodynamic models were set up, two in the winter scenario and two in the summer, one considering density gradients generated by salinity variations and one disregarding these gradients. Other than that, in each season of the year the models have the same input data, boundary and initial conditions, as described below.

\section{Computational model adopted}

The computational simulations were performed with the environmental hydrodynamic base system, entitled SisBaHiA, a professional system of computational models registered by COPPE/UFRJ - Alberto Luiz Coimbra of Post-Graduation and Research of Engineering Institute of the Federal University of Rio de Janeiro. Further details can be obtained at the SisBaHiA website (COPPE, 2019), where one can also download and install SisBaHiA.

This model system was adopted for its applications versatility and its proven reliability in the face of extensive use in various researches, projects and studies to support environmental management of water resources, which are listed in the items "Research - Theses" and "Applications - Projects" on the website. In addition to the works listed on this website, there are papers published in journals such as Feitosa et al. (2013), Roversi, Rosman and Harari (2016a, b), Silva \& Rosman (2016), Peixoto et al. (2017), Sawakuchi et al. (2017), Barros and Rosman (2018) and Cunha et al.(2018). The models implemented therein can be used to predict the flow of water and the transport of scalar quantities of interest. This system can be applied in simulations of scenarios in coastal waters, bays, estuaries, rivers, canals, reservoirs, lakes or ponds, aiming to understand the dynamics of processes in these complex environmental systems (ROSMAN, 2018).

\section{Hydrodynamic model}

The SisBaHiA has hydrodynamic models designed to represent flows in water bodies with complex geometry, as usual in natural systems.

Flows with horizontal movement scales at least 20 times larger than the depth can be considered as shallow water flows (DEAN; DALRYMPLE, 2001). This is the case for most 
geophysical flows, such as rivers, reservoir estuaries and even oceans. In this situation the pressure field can be considered as almost hydrostatic. The Guanabara Bay fits in this case, in addition, it tends to be vertically homogeneous. It justifies the application of a vertically integrated hydrodynamic model, that is, two-dimensional horizontally, also known as $2 \mathrm{DH}$.

In these situations, the differential equations of movement, called shallow water equations, are deduced from the general equations of flows in turbulent regime, known as Navier-Stokes equations, which express the principles of mass conservation and balance of movement quantity via Newton's second law. Analytical and numerical deductions of the equations are available in the technical reference of SisBaHiA (ROSMAN, 2018).

\section{Eulerian transport model}

The Eulerian Transport Model carries out the simulation of advective-diffusive transport with kinetic reactions of production or consumption of constituent substances present in the water. When the constituent has an active behavior, that is, it generates pressure gradients that influence in a relevant way the water flow, such as salinity gradients, the transport of the constituent can be coupled to the hydrodynamic model. When the behavior of the constituent is passive, i.e., it does not interfere significantly in hydrodynamics, the solution of the transport problem can be decoupled from the hydrodynamic model.
In this study, the water quality model in SisBaHiA was used to simulate the salinity transport coupled to the hydrodynamic model. The spatial variation of salinity generates pressure gradients by differences in water density, or baroclinic forces.

\section{Modeling steps}

This section describes the development of computational models generated for the analyses presented.

\section{Modeling domain and discretization mesh}

The definition of the modeling domain comprehends the initial step of building the model. In general, the land contours, i.e., with flow control, are associated with land borders and include the continental and island coastline, as well as margins and cross-sections of upstream rivers. Open contours have free flow, but specified levels, and usually delimit the encounter of the modeled water body with the outer water body. The geometry of the study area was digitized from Google Earth Pro images dated December 2016.

The spatial discretization, represented in Figure 1, uses 2284 finite elements, of which 2185 are biquadratic quadrangular and 99 quadratic triangular, allowing a detailed representation of the main contours of natural water bodies. In total there are

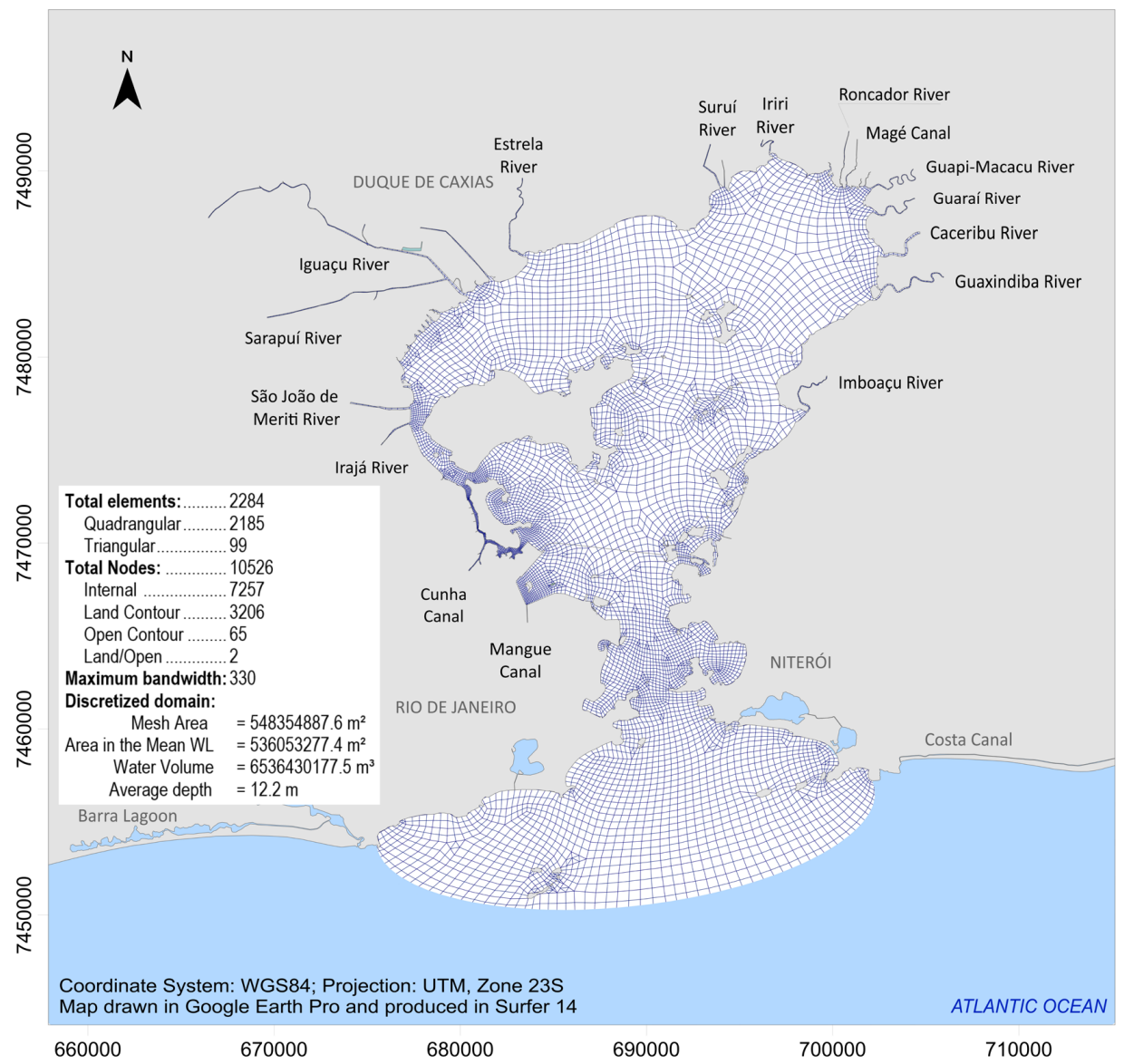

Figure 1. Discretization mesh of the modeling domain for the Guanabara Bay. 
10526 calculation points. In each element node there are 4 variables: elevation of the free surface, $x$ and $y$ components of velocity and salinity, which makes a total of 42104 equations resolved every step of time.

Data of bathymetry for the model were extracted from nautical charts of the Direction of Hydrography and Navigation of the Brazilian Navy (DHN). Specifically, the nautical charts: CN: 1501 - Baía de Guanabara, 1511 - Barra do Rio de Janeiro, 1512 - Porto do Rio de Janeiro, 1513 - Terminais da Baía de Guanabara, 1515 - Baía de Guanabara - Ilha do Mocanguê e Proximidades e 1531 - Baía de Guanabara - Ilha do Boqueirão e Adjacências. All bathymetry data were compatibilized with the reduction level adopted by DHN in CN 1512. The results shown in Figure 2 are relative to the Mean Sea Level (MSL), which is $0.7 \mathrm{~m}$ above the reduction level of CN 1512 .

The distribution of bottom sediments adopted is illustrated in Figure 3 and follows data collected in the period from 1985 to 1996 . This distribution was initially presented by Amador in 1992, and updated in 1996 by Quaresma \& Dias, from new measurements carried out by DHN and the Marine Geology Laboratory of Fluminense Federal University (LAGEMAR-UFF) (AMADOR, 1997). It was identified that the northern region of the bay is composed, mostly, by clays and silts, while the central channel and the mouth region present mostly fine to medium and some coarse sands.

Amplitude values of the bottom equivalent roughness for each sediment class were defined as suggested in Rosman (2018). Previous modeling work was also considered in Guanabara Bay, such as Andrioni (2013), Kaufmann (2009), Malta (2005) and Sampaio (2003).

\section{Models conditioners}

To simulate circulation patterns and their seasonal variation, two scenarios were adopted in the hydrodynamic modeling, one representative of winter (dry season) and another of summer (rainy season):

- Winter 2016: from 06/20/2016 to 09/22/2016;

- Summer 2016/2017: from 12/21/2016 to 03/20/2017.

The scenarios considered the start and end dates of the season in the year analyzed, from the summer solstice to the autumn equinox for the summer season, and from the winter solstice to the spring equinox for the winter season.

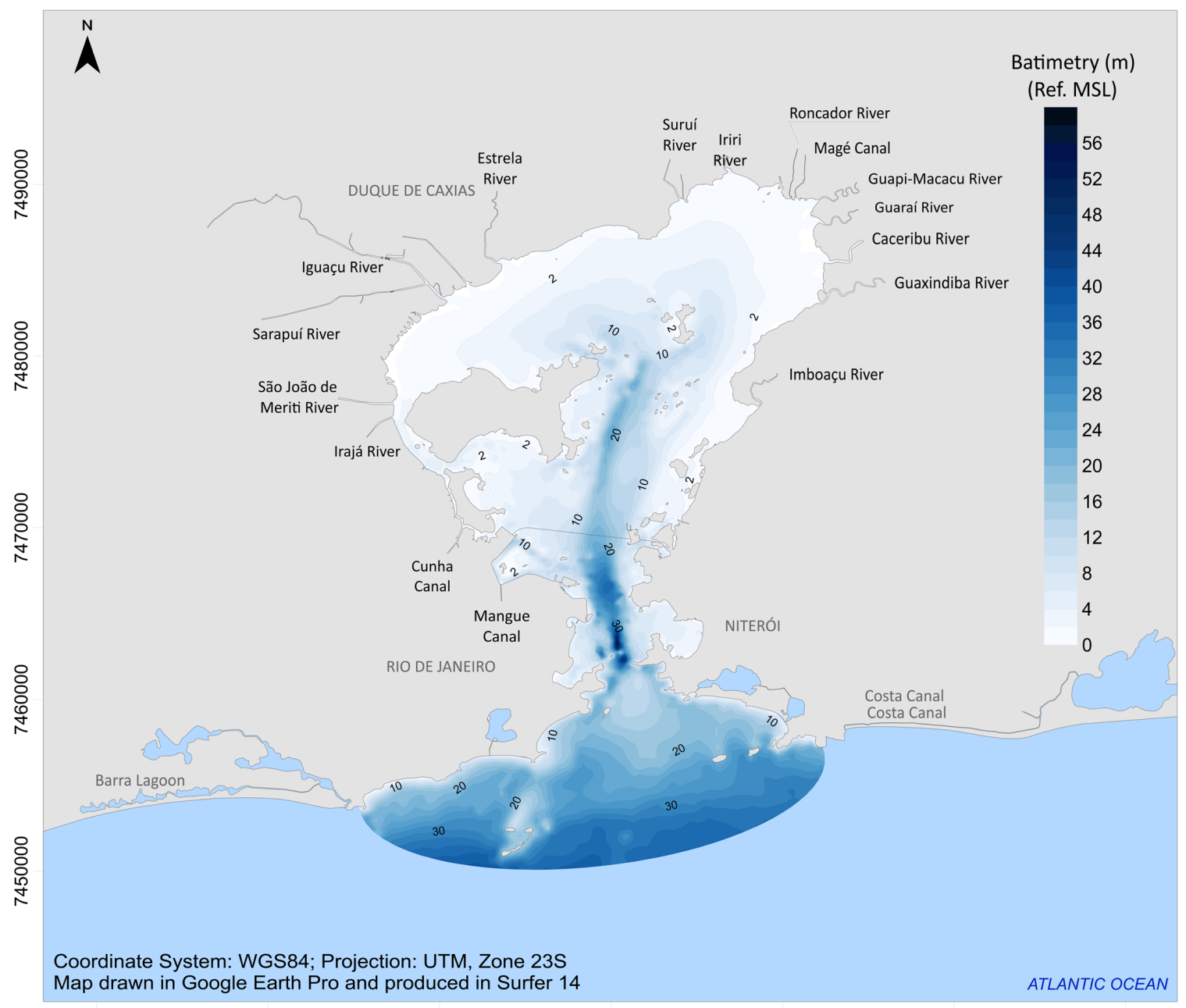

Figure 2. Bathymetry used by the model. 


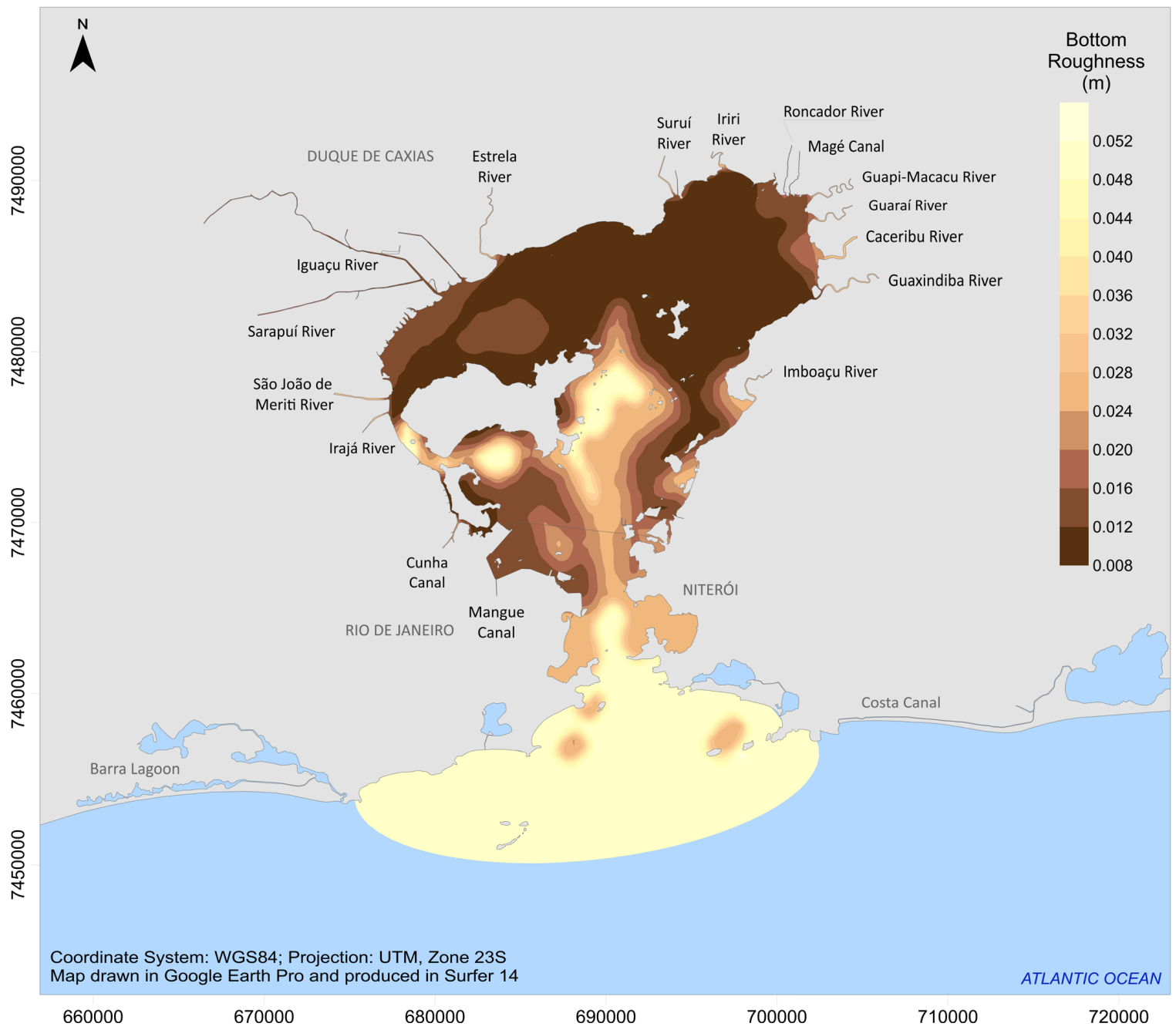

Figure 3. Characterization of the bottom roughness amplitude ( $\varepsilon$ ) according granulometry from Amador (1997).

The models include the following forcing terms for the simulated periods: tidal levels, coastal currents, winds and river inflows, detailed below.

Tides

As a boundary condition for the open border of the domain, time series of free surface elevations were prescribed for each mesh point. The series were obtained from the harmonic constituents of the Rio de Janeiro Port station (Fiscal Island) - RJ, calibrated to the open boundary, in order to reproduce the tidal curves at the Fiscal Island station. It also included the meteorological effects in the MSL extracted from daily average sea elevation data computed by the Hybrid Coordinate Ocean Model (HYCOM). Daher et al. (2016), in a study on the coast of Rio de Janeiro, show that the values of the HYCOM model adequately represent the daily average level data obtained from measurements, validating its use for boundary conditions of regional models. The data were downloaded through the tool "Extract information from HYCOM" in SisBaHiA, to a point located in the central region of the open boundary, with coordinates $43^{\circ} 7^{\prime} 12^{\prime \prime}$ West (W) e $23^{\circ} 2$ '24"South (S).
The elevation conditions inserted in the open boundary of the model were calculated by the sum of the astronomical tide and meteorological MSL series. Figure 4 presents the conditions for the entire simulation period, one for winter and another for summer.

Series of elevations were inserted in the open boundary, with a lag between each node of the boundary considering the distances and depths from west to east.

\section{River inflow}

An important aspect in the study of the hydrodynamics of Guanabara Bay is the freshwater input, which this estuarine system receives from the rivers inflows. For the winter period, from June 20 to September 22, the inflows are typical of dry season with little variation, so it was considered the inflow with permanence in $95 \%$ of the time $\left(\mathrm{Q}_{95 \%}\right)$ as representative of the whole period. For the summer, a rainy season, there are significant variations over the months, so it was considered monthly averaged values from December 21 to March 20. The use of $\mathrm{Q}_{05}$ and average inflows considered the high deficit of consistent series of data from in situ water discharge measurements of rivers in the watersheds that 

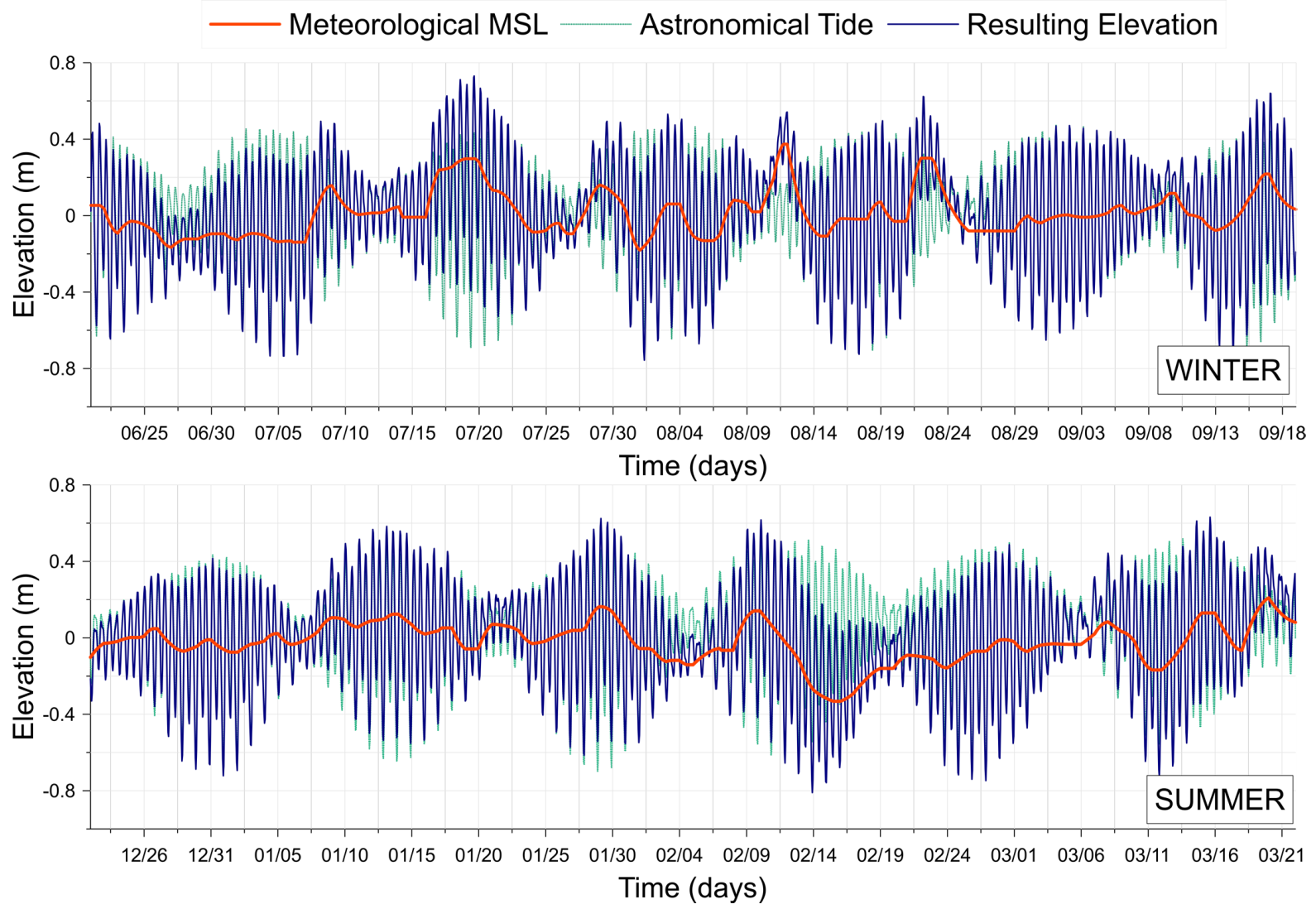

Figure 4. Time series of astronomical tide elevation combined with the meteorological MSL for winter and summer months.

flow into the bay. However, it is noteworthy that for the purposes of this study, the use of monthly average inflows is enough. In addition, effects of large short-term rainfall in summer would generate medium-level variations that would hinder the analysis of the effects of relatively more subtle salinity gradients.

These inflows were obtained from regionalization studies conducted for the Guanabara Bay tributary basins, based on consisted data from historical water level series and discharge measurements from river basin stations.

For the basins of the rivers Surui, Iriri, Santo Aleixo, Guapi-Macacu, Guaraí, Caceribu and Magé canal were used the regionalization equations of $\mathrm{Q}_{95 \%}$ obtained in the state Plan of Water Resources of Rio de Janeiro-PERHI-RJ, published in 2014 (PERHI, 2014). For these rivers, the flow of the rainy season was obtained by means of regionalization equations using consisted data from the fluviometric posts used in the PERHI-RJ. In the other basins, including Mangue canal, Cunha canal, Penha canal, Irajá river, São João de Meriti river, Sarapuí river, Iguaçu river, Estrela river, the flow rates with 95\% permanence in time and the inflows in the rainy season were obtained from the study developed by LABH2O (2016).

The inflows of the rivers for winter and summer considered in the simulations are listed, respectively, in Table 1 and Table 2.

\section{Coastal currents}

On the southern coast of the state of Rio de Janeiro, the continental shelf follows approximately the East (E) - West (W) direction, guiding the coastal currents to follow this direction,
Table 1. Minimum winter inflows per sub-basin adopted in the models.

\begin{tabular}{lrc}
\hline \multicolumn{1}{c}{ Sub-Basin } & $\begin{array}{c}\text { Drainage Area } \\
\left(\mathbf{k m}^{2}\right)\end{array}$ & $\mathbf{Q}_{\mathbf{9 5 \%}} \mathbf{( \mathbf { m } ^ { 3 } / \mathbf { s } )}$ \\
\hline Mangue Canal & 44.83 & 1.72 \\
Cunha Canal & 62.20 & 2.25 \\
Vila do João Canal & 2.03 & 0.78 \\
Dom Carlo River & 1.78 & 0.07 \\
Irajá River & 17.47 & 0.67 \\
Penha Canal & 12.99 & 0.50 \\
São João de Meriti River & 167.20 & 4.45 \\
Sarapuí River & 123.38 & 4.13 \\
Canal (in the Sarapuí River) & 7.53 & 0.20 \\
Bota River & 119.00 & 0.96 \\
Iguaçu River & 256.44 & 1.74 \\
Capivari River & 100.22 & 0.68 \\
Pilar River & 29.70 & 0.42 \\
Estrela River & 327.24 & 2.22 \\
Suruí River & 79.62 & 1.23 \\
Suruí Mirim River & 4.99 & 0.12 \\
Iriri River & 19.67 & 0.42 \\
Roncador River & 115.43 & 1.37 \\
Magé Canal & 16.47 & 0.37 \\
Guapi-Macacu River & 1264.01 & 10.04 \\
Guaraí River & 17.49 & 0.38 \\
Caceribu River & 796.73 & 7.00 \\
Guaxindiba River & 176.11 & 1.08 \\
Imboaçu River & 30.58 & 0.19 \\
Total & 3793.13 & 42.49 \\
\hline
\end{tabular}


Andrade et al.

Table 2. Data of summer river inflows per sub-basin adopted in the models.

\begin{tabular}{|c|c|c|c|c|c|}
\hline \multirow{2}{*}{ Sub-Basin } & \multirow{2}{*}{$\begin{array}{c}\text { Drainage Area } \\
\left(\mathrm{km}^{2}\right)\end{array}$} & \multicolumn{4}{|c|}{ Average flow rate } \\
\hline & & Dez & Jan & Feb & Mar \\
\hline Mangue Canal & 44.83 & 3.55 & 3.59 & 3.33 & 3.67 \\
\hline Cunha Canal & 62.20 & 4.60 & 4.68 & 4.33 & 4.78 \\
\hline Vila do João Canal & 2.03 & 0.16 & 0.16 & 0.15 & 0.17 \\
\hline Dom Carlo River & 1.78 & 0.14 & 0.14 & 0.13 & 0.15 \\
\hline Irajá River & 17.47 & 1.38 & 1.40 & 1.30 & 1.43 \\
\hline Penha Canal & 12.99 & 1.03 & 1.04 & 0.96 & 1.06 \\
\hline São João de Meriti River & 167.20 & 8.30 & 9.10 & 7.55 & 8.60 \\
\hline Sarapuí River & 123.38 & 7.91 & 8.57 & 7.12 & 8.05 \\
\hline Canal (in the Sarapuí River) & 7.53 & 0.37 & 0.41 & 0.34 & 0.39 \\
\hline Bota River & 119.00 & 7.31 & 5.28 & 4.42 & 3.41 \\
\hline Iguaçu River & 256.44 & 5.16 & 3.73 & 3.12 & 2.41 \\
\hline Capivari River & 100.22 & 13.20 & 9.53 & 7.99 & 6.16 \\
\hline Pilar River & 29.70 & 3.20 & 2.31 & 1.94 & 1.50 \\
\hline Estrela River & 327.24 & 16.85 & 12.16 & 10.19 & 7.87 \\
\hline Suruí River & 79.62 & 8.02 & 7.68 & 6.83 & 6.49 \\
\hline Suruí Mirim River & 4.99 & 1.00 & 0.80 & 0.76 & 0.77 \\
\hline Iriri River & 19.67 & 3.23 & 2.74 & 2.55 & 2.55 \\
\hline Roncador River & 115.43 & 9.58 & 9.66 & 8.43 & 7.87 \\
\hline Magé Canal & 16.47 & 2.96 & 2.43 & 2.28 & 2.29 \\
\hline Guapi-Macacu River & 1264.01 & 44.91 & 57.28 & 46.10 & 39.46 \\
\hline Guaraí River & 17.49 & 3.00 & 2.49 & 2.32 & 2.33 \\
\hline Caceribu River & 796.73 & 33.24 & 40.52 & 33.12 & 28.83 \\
\hline Guaxindiba River & 176.11 & 6.69 & 9.27 & 8.42 & 9.16 \\
\hline Imboaçu River & 30.58 & 1.16 & 1.61 & 1.46 & 1.39 \\
\hline Total & 3793.13 & 187.04 & 196.59 & 165.14 & 151.00 \\
\hline
\end{tabular}

parallel to the overall coastline. The direction of currents varies according to the influence of factors such as propagation of platform waves, winds and frontal systems (MELO FILHO, 2017).

To represent this pattern of currents, a series of differential mean level (DML) was prescribed as an additional boundary condition along the open boundary nodes. The temporal series generating the DML was the series of average daily velocities in the E-W direction extracted from HYCOM data at a point near the middle of the open boundary, at a depth of $10 \mathrm{~m}$ from the surface. These data were also extracted from HYCOM through the tool "Extract information from HYCOM" in SisBaHiA.

The values of daily average currents generated by the DML series were calibrated to correspond to typical values measured in the region. These typical values were obtained in campaigns of oceanographic measurements on the coast of Rio de Janeiro carried out by the laboratory of tracers of COPPE/UFRJ, in the period from November 29, 1996 to January 15, 1998 (CARVALHO, 2003), performed to subsidize dispersion studies at the Ipanema Sewerage Submarine Emissary (ESEI).

\section{Winds}

Wind shear stress on the free surface of the water is calculated from wind direction and intensity data. In all computational simulations of this work the wind was considered variable in time and varied in space. Wind data were obtained from the ERA-Interim reanalysis model of the European Centre for
Medium-Range Weather Forecasts - ECMWF (2017), available in ER-Interim Daily, which includes wind data since 01/1979. The minimum interval between available data at the time of this study is 6 hours. This was the data range introduced in the models, which internally interpolate quadratically to the time step of the model. The wind data were spatially distributed by the nodes of the elements in the domain from the data in the seven stations of the ERA-Interim indicated in Figure 5.

\section{Salinity}

The hydrodynamic model initially ran without the computation of baroclinic pressure gradients. A model of salinity transport was then run, using the results of the hydrodynamics first generated. This uncoupled simulation of salinity transport aimed at generating the initial salinity condition to be used in the following model. This stage is of great importance because if the model started with an initial condition with a generic salinity value for the entire domain, much of the simulated period would be for stabilization of salt concentrations. To start the simulation with values already coherent and grounded in data measured throughout the domain increases the quality of the results. The salinity distribution for initial condition was based on field data obtained by Bérgamo (2006), Guimarães et al. (2011) and Santos (2015).

After proper initial salinity distribution, the salinity transport model ran coupled to the hydrodynamic model to generate density gradients for the hydrodynamics. Conceptually, density gradients 
in estuaries such as GB depend fundamentally on the variation of salinity, because the small variations in temperature generate density effects about 50 times smaller than those caused by salinity variations. For this reason, temperature was not considered as an active constituent for the generation of density gradients.

The initial conditions of salinity adopted in the models are shown in Figure 6, for the winter period, and in Figure 7 for the summer.

With the results of the hydrodynamic models without pressure gradient due to salinity variations, and the models that considered this forcing through the coupling of the salinity transport model, the comparisons and analyzes described below were made. It is noteworthy that there are many applications of SisBaHiA models in Guanabara Bay with proven reliability, with academic works such as Pereira (2017), Andrioni (2013), Kaufmann (2009), Malta (2005) and Sampaio (2003), in addition to contracted technical projects through the COPPETEC Foundation, for example projects in support of the National Dredging Program of the National Secretariat of Ports of the Ministry of Transports of the Federal Government of Brazil (COPPETEC, 2012; 2015; 2016).

\section{RESULTS AND DISCUSSIONS}

This item initially presents a characterization of the hydrodynamic circulation in Guanabara Bay, followed by the description of salinity patterns in the model domain and, finally, analyses of the effect of the horizontal density gradient on the results of average water level.

The graphical results refer to the points highlighted in Figure 8.

\section{Hydrodynamic characterization}

A characteristic of Guanabara Bay hydrodynamics is the increase in tidal heights, accompanied by a lag as the tide travels to the interior of the bay, as can be seen in Figure 9. In this context, it can be said that GB is a hypersynchronous estuary (DYER, 1997).

The tidal wave in the bay tends to be of stationary type, therefore, in moments of high water (HW) and Low water (LW) the current velocities tend to their smallest values, close to zero.

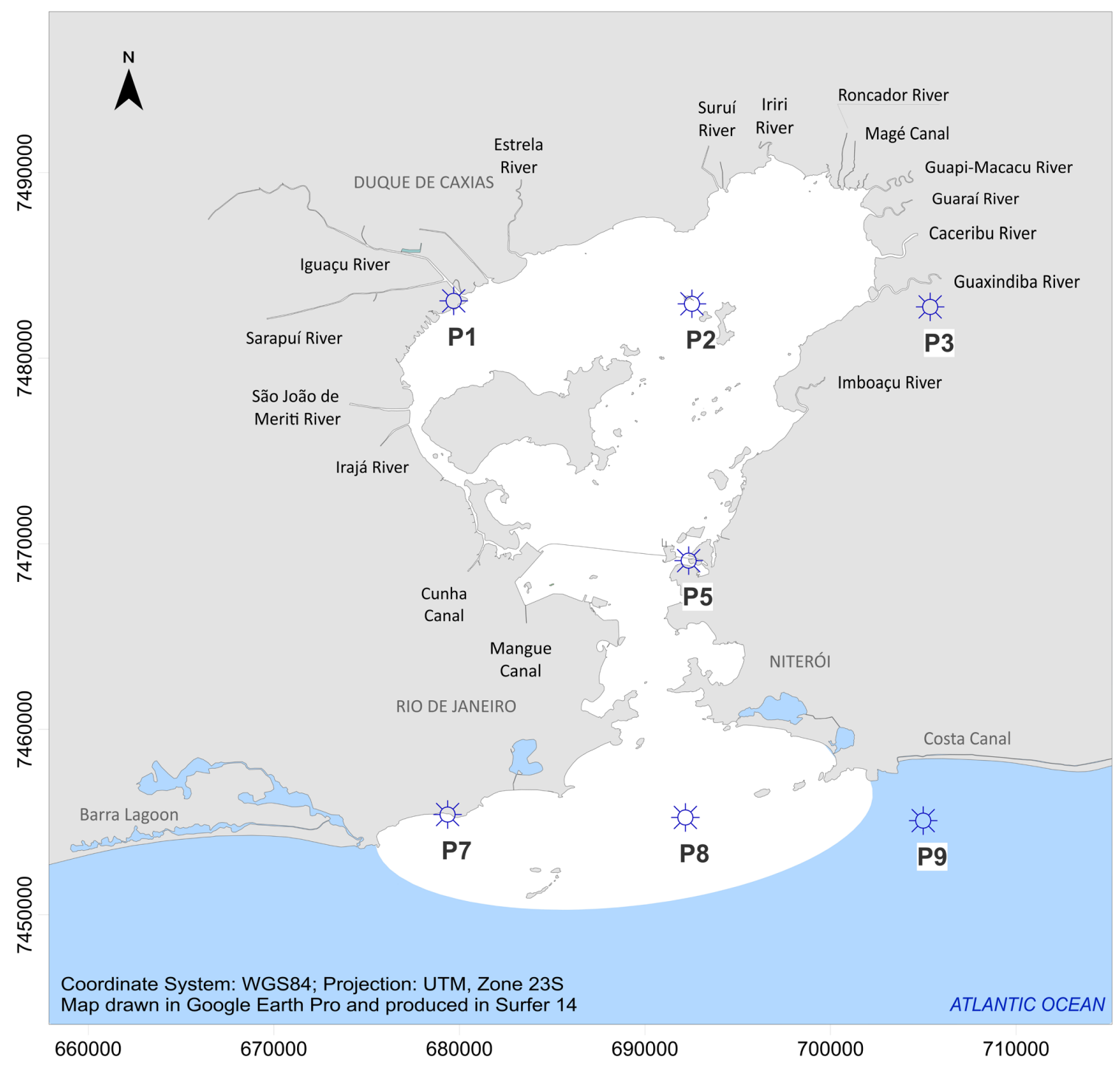

Figure 5. Location of the 7 ERA-Interim stations used to extract winds data from reanalysis. 


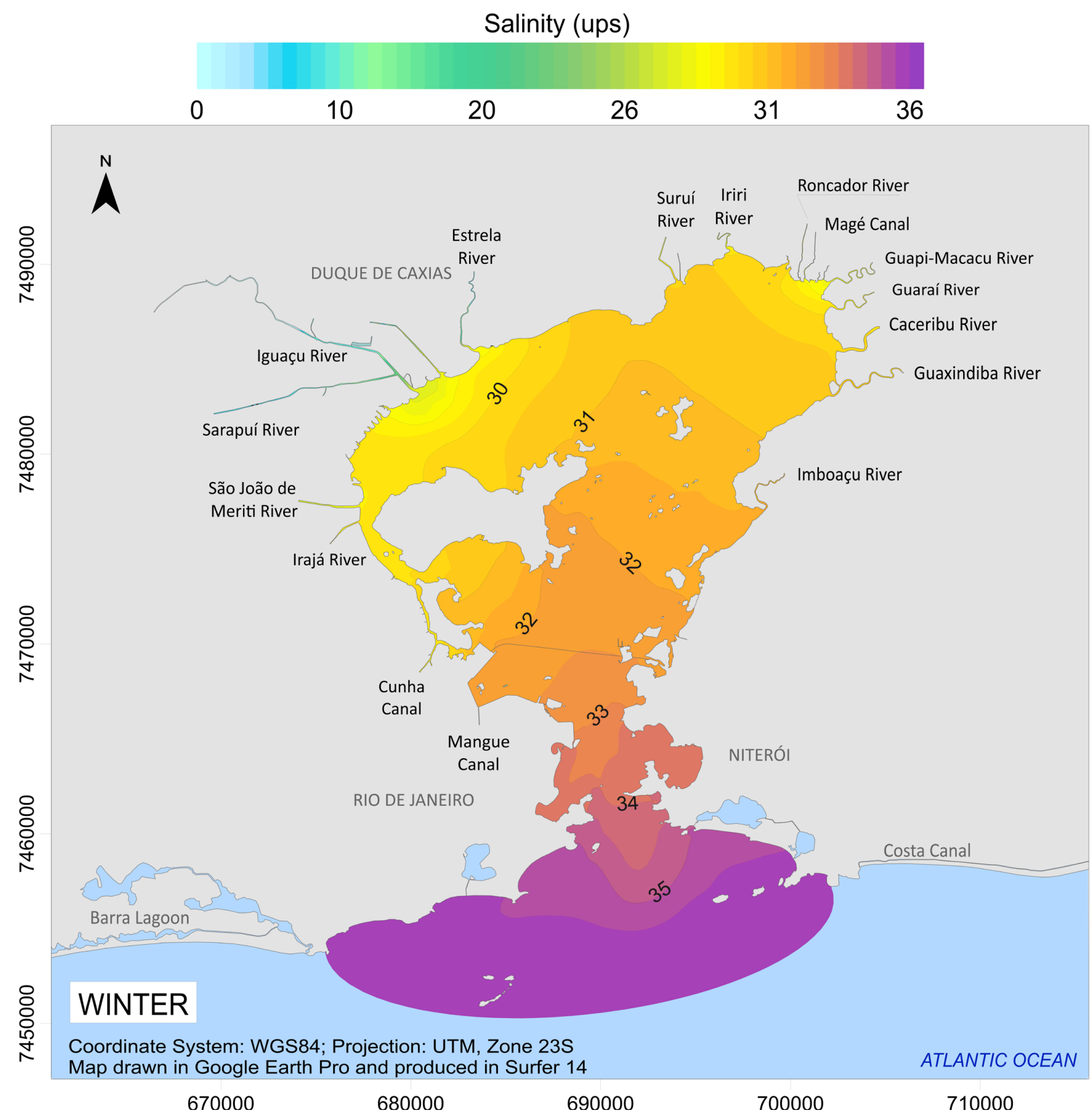

Figure 6. Distribution of initial salinity condition in GB for winter models.

And in moments of mid-ebb tide (MET) and mid-flood tide (MFT) the magnitudes of currents reach the highest values. Such moments are highlighted with dashed lines in Figure 10, which shows values at the Rio-Niterói Bridge station.

It is noticeable that the variation of currents in the interior of Guanabara Bay, with floods and ebbs, is more strongly related to the astronomical tide. On the other hand, coastal currents have a very strong linkage with the effects of meteorological MSL variations, due to platform waves or meteorological events such as weather front arrivals. These coastal currents are of great importance in the renewal of the waters of the bay.

Movements in the N-S direction are more intense in the Bay Mouth region than in the interior of the bay. This is due to the narrowing of its mouth.

\section{Characterization of salinity distribution}

The Guanabara Bay receives saline water from the sea, with salinity 36 ups and specific mass of about $1025 \mathrm{~kg} / \mathrm{m}^{3}$, and freshwater of the rivers, with salinity close to 0 and specific mass of about $998 \mathrm{~kg} / \mathrm{m}^{3}$. The combination of these waters with different densities generates baroclinic pressure gradients due to the reduction of salinity concentration as it enters the bay. Works such as those of Bérgamo (2006), Guimarães et al. (2011) and Santos (2015) recorded this pattern in field data, gathering values in different points in accordance with the isoline maps of Figure 6 and Figure 7.

In a general analysis of the variability of salinity within tidal phases, quite small differences were observed between spring 


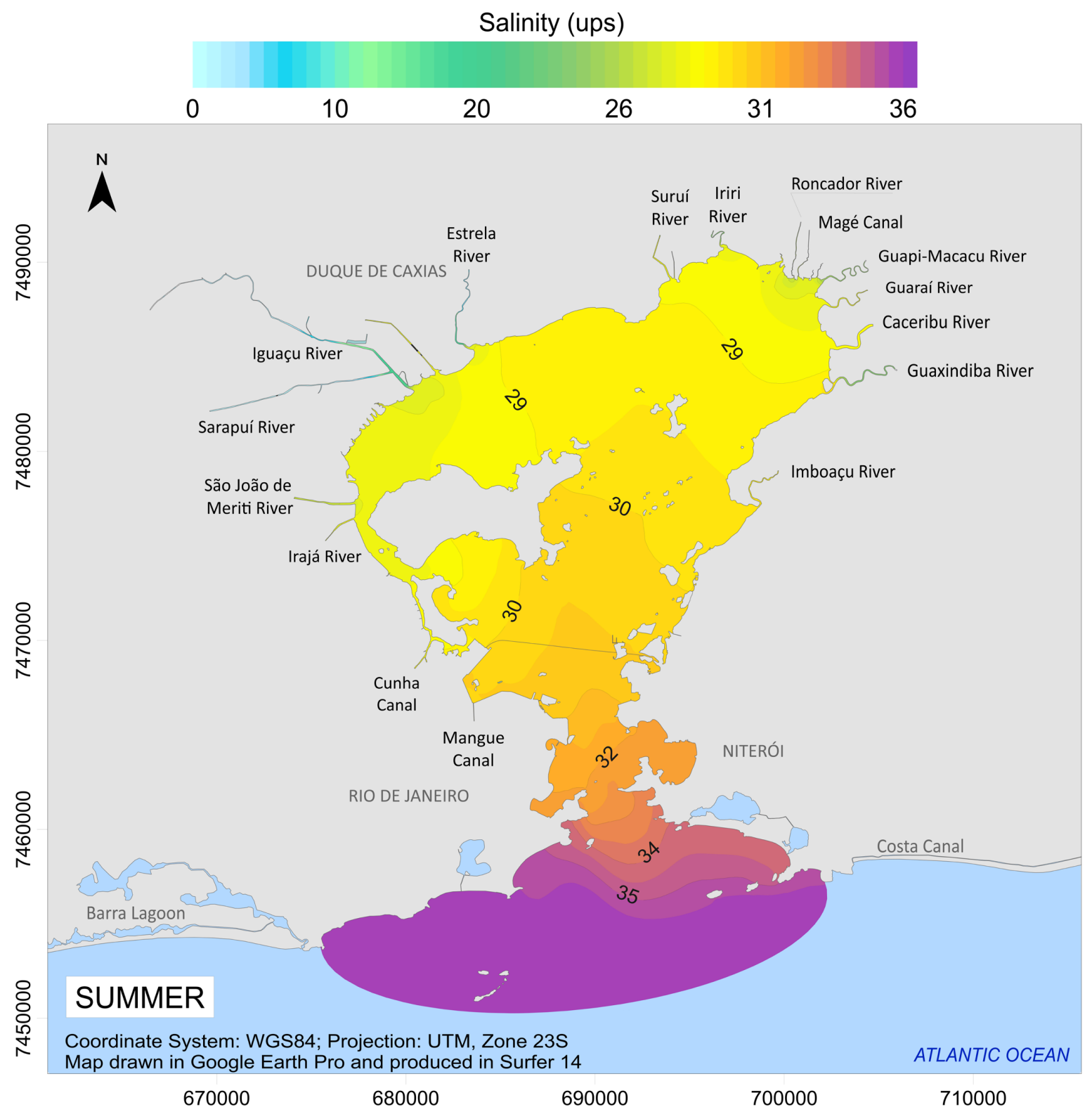

Figure 7. Distribution of initial salinity condition in GB for summer models.

and neap tides, for the same fluvial conditions. Such behavior is justified by the long time needed for water renewal in Guanabara Bay. Renewal time varies significantly in different areas of the bay, from weeks to months. The intervals of spring and neap tides vary around 7 days, insufficient time to distinguish significant differences in the general salinity concentration of the bay. In both seasons, winter and summer, similar distribution patterns were observed between spring and neap tides in the same season.

Comparing the results for winter and summer, one can observe the influence of affluent river inflow on salinity. In summer lower salinity values are found in the interior of the bay. Which is consistent due to the higher freshwater inflow in this period. In this study, based on historical data, a total freshwater input in GB of $42.5 \mathrm{~m}^{3} \cdot \mathrm{s}^{-1}$ was considered, according $\mathrm{Q}_{95 \%}$ adopted in winter, and $175 \mathrm{~m}^{3} \cdot \mathrm{s}^{-1}$ in summer. Therefore, in summer the inflow to the Bay is about 4 times higher than in winter.
Salinity reaches its highest values in the main channel of Bay, near the Bay Mouth, and the lowest values, as expected, are found near the mouths of the higher inflow rivers, such as Iguaçu-Sarapuí, Guapi-Macacu and the Caceribu Rivers.

\section{Changes in the mean level due to the baroclinic pressure gradient}

For both winter and summer scenarios, it was observed that, in the model without baroclinic pressure gradient mean water levels were underestimated. However, the difference is small, reaching 5 centimeters. The largest value in the northwest region of the Bay and the smallest value in Bay Mouth.

Figure 11 and Figure 12 display graphs of average water level values calculated for each modeled month. The seasonal variation in the intensity of the baroclinic pressure gradient is remarkable. 


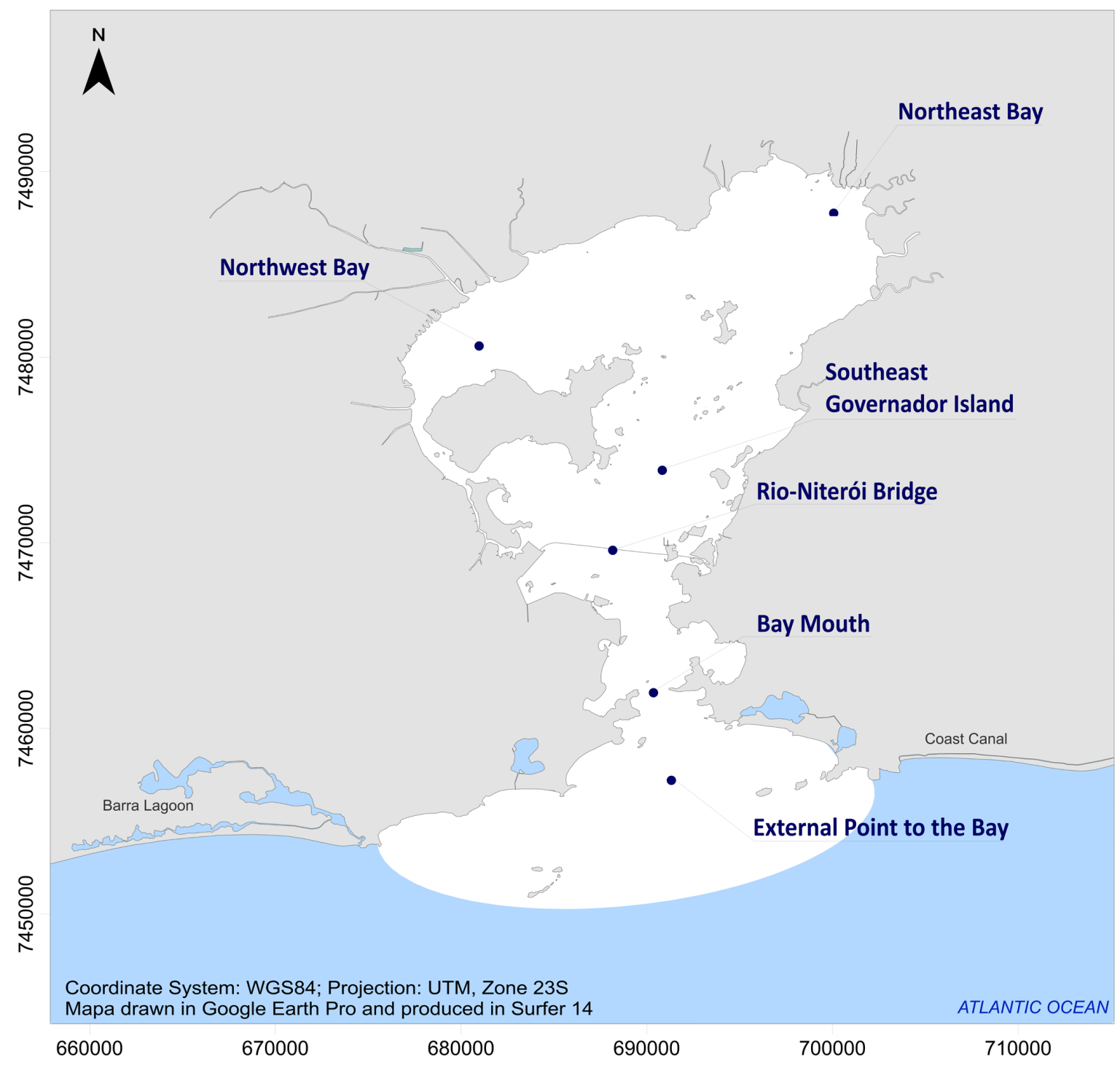

Figure 8. Reference stations for analysis of results.



Figure 9. Time series of elevation of water level in the control stations External Point to the Bay, Rio-Niterói Bridge and Northeast Bay, for a tidal cycle in the first 25 hours of simulation. 


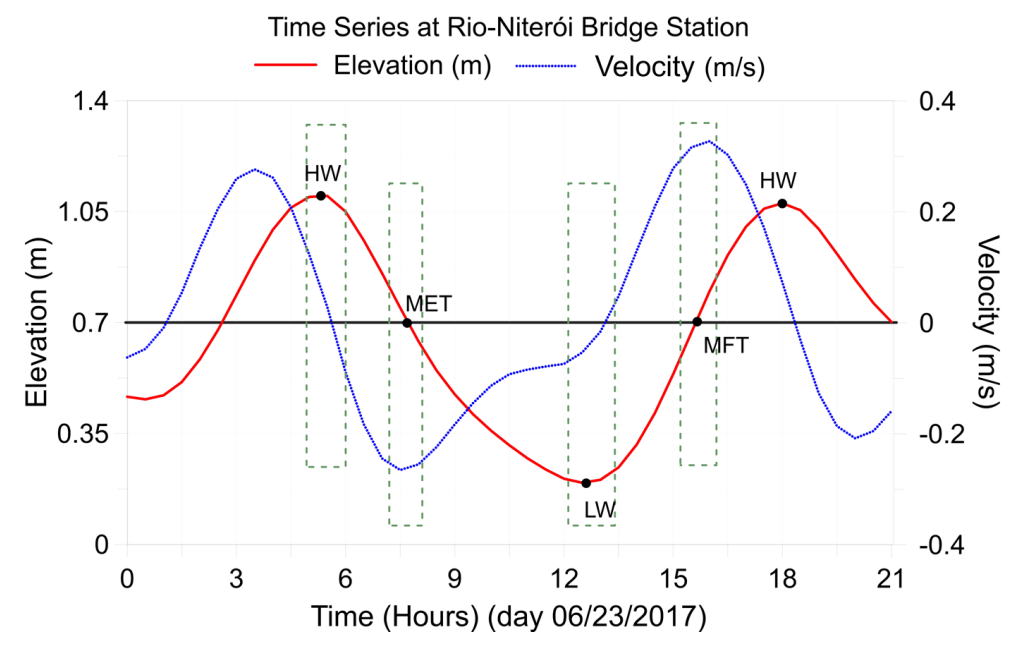

Figure 10. Time series of elevation and velocity of currents for a spring tide in December 2016, at the Rio-Niterói Bridge station. Highlighting the characteristic of almost stationary tidal wave.

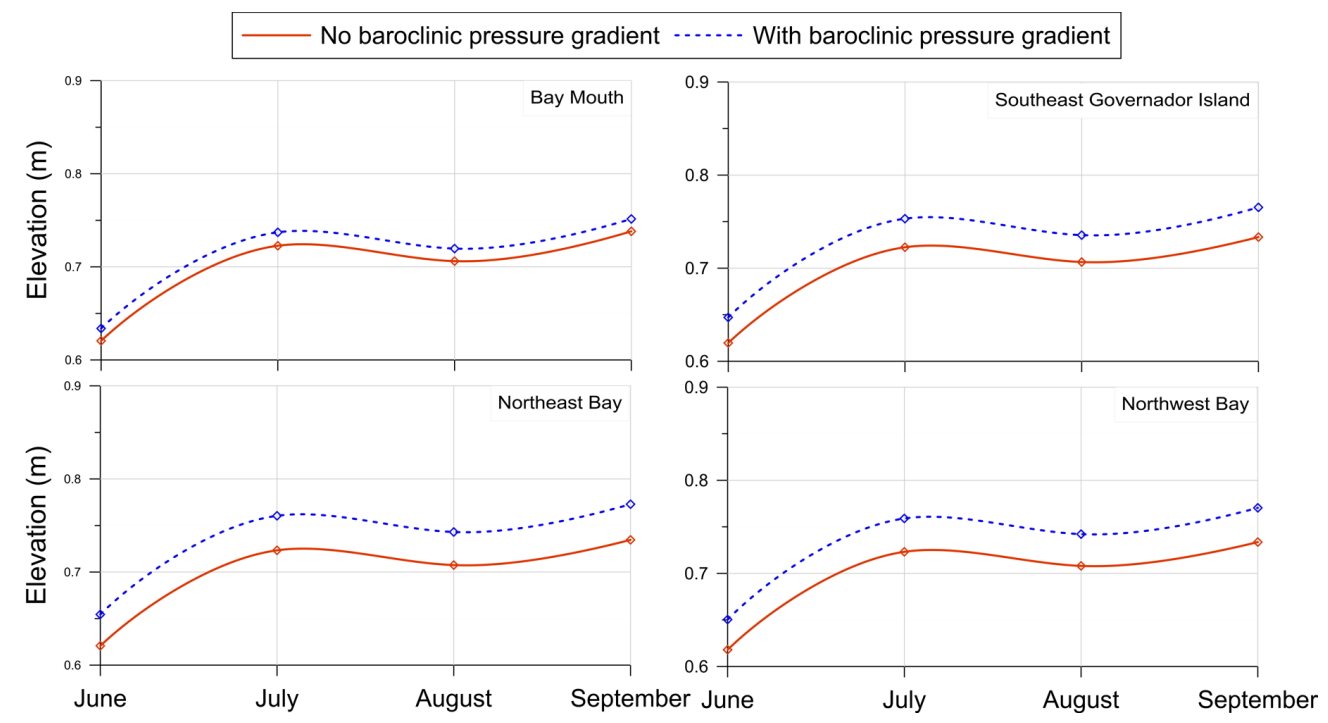

Figure 11. Relation between monthly water level elevations with and without baroclinic pressure gradient for the winter months.

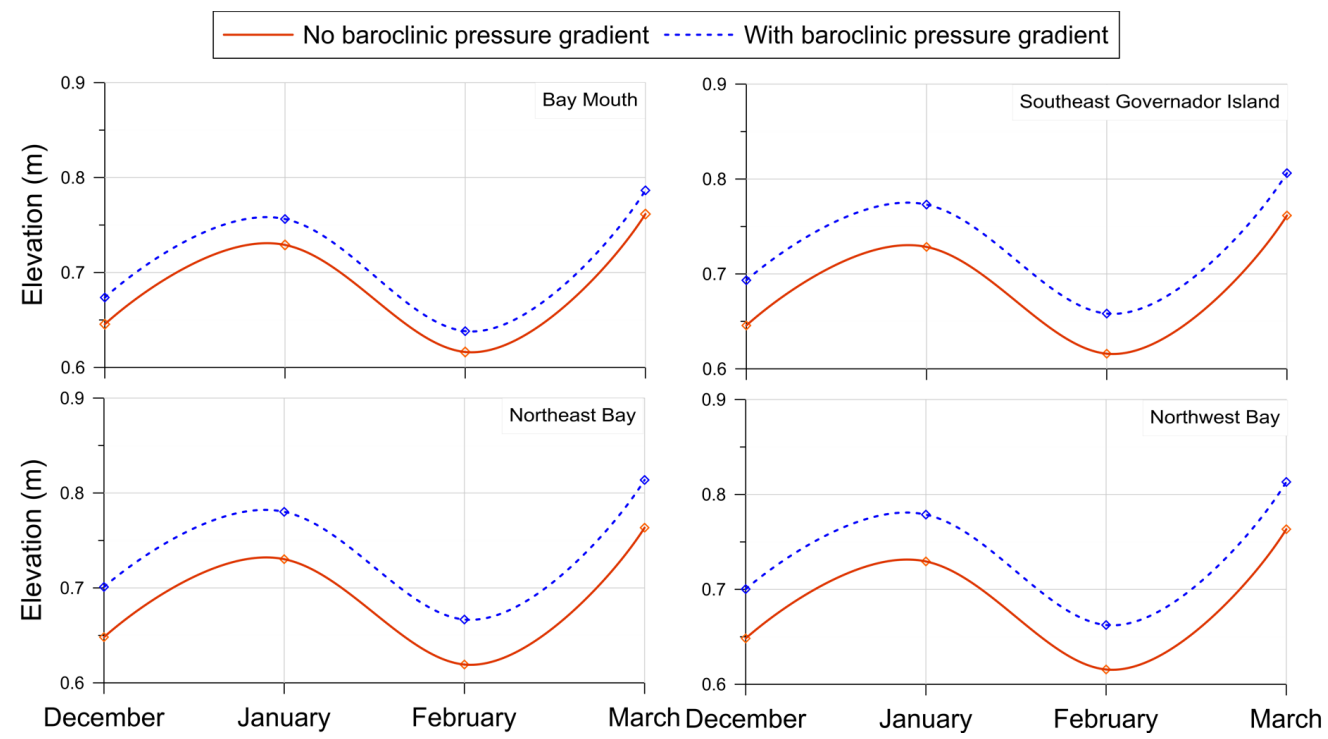

Figure 12. Relation between monthly water level elevations with and without baroclinic pressure gradient for the summer months. 

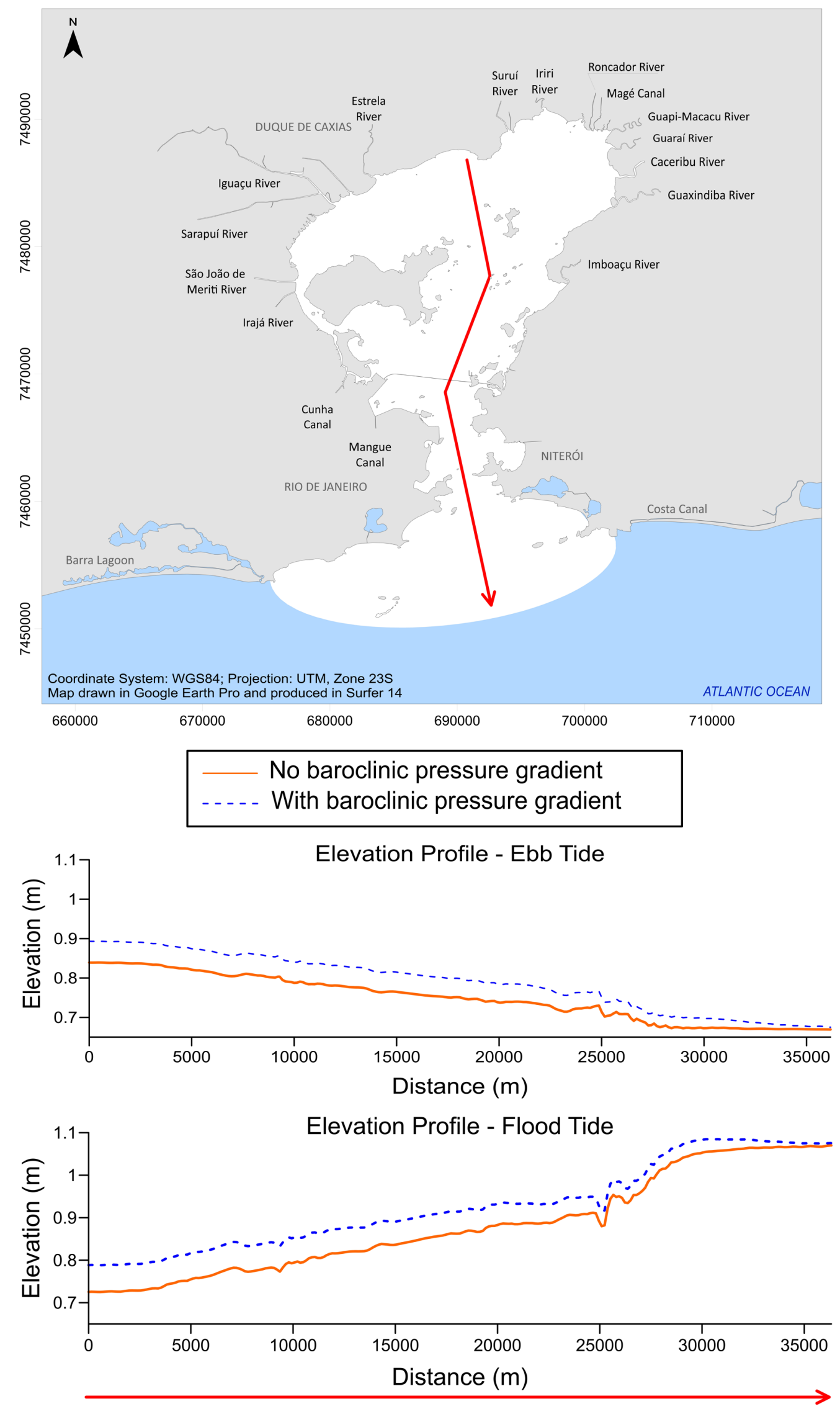

Figure 13. Illustration of water levels along a profile from north to south in Guanabara Bay, referring to the instants of mid-ebb and mid-flood tides in summer. In winter the behavior is similar with smaller differences, going up to $3 \mathrm{~cm}$. 
In summer, when river inflows are higher, as already discussed, the gradient effect is greater. While in winter this gradient has less effect on water levels. It should be noted that in order to evaluate the effects of density gradients on the mean monthly levels of GB, sudden events of peak inflow due to heavy rains, due to its short duration, typically less than one day, are not relevant.

The oscillations observed over the months stem from the influence of the meteorological effects. Thus, it can be highlighted that the influence of the baroclinic pressure gradient at mean water levels for each point observed practically does not vary throughout the year. This is evidenced by the differences in the mean levels between the models with and without salinity observed in the graphs.

Also from the graphs of Figure 11 and Figure 12, it can be seen that in the region of the Bay Mouth the effect of the baroclinic pressure gradient is lower than in the other regions of the bay. This is explained by the smaller variations of salinity in this region, which is close to the sea, more salty. In addition to presenting higher current velocities and consequent greater mixing.

Inside the bay, mainly in the extreme northwest and northeast regions, the influence of freshwater from the rivers on local salinity is stronger, which amplifies the effect of baroclinic pressure gradients. Differences in the average level of up to 3.8 centimeters were computed in the winter, and up to 5.3 centimeters in the summer.

The variation of the effect of the baroclinic pressure gradient on the water levels along the GB is well illustrated in Figure 13, which shows instantaneous levels of water in the bay along a profile extending from the north of GB to the sea.

As illustrated by the maps of Annex I, there are no significant differences in the patterns of hydrodynamic circulation due to the effects of braroclinic pressure gradient. It is concluded that the influence is stronger in the elevation of water level. To illustrate this result, Annex I presents the patterns of hydrodynamic circulation in instants of HW, MET, LW and MFT, for the results of the models without baroclinic pressure gradient and with the gradient.

\section{CONCLUSIONS}

The study shows that the non-inclusion of baroclinic pressure gradients decreases the mean monthly water level in GB from 0 to $5 \mathrm{~cm}$ depending on the sector. However, the patterns of 2DH hydrodynamic circulation with and without density gradients are practically indistinguishable, as shown by the comparative maps in Annex I. Through the analyses presented, it is concluded that:

- Modeling without the inclusion of salinity as an active constituent, that is, without the force of baroclinic pressure gradients in hydrodynamics, can underestimate the mean water level in Guanabara Bay in values ranging from almost 0 at the entrance of the bay to up to $5 \mathrm{~cm}$ in Northern region, the area with the largest river inflows, as shown in Figure 13.

- For the purposes of analysis of 2DH hydrodynamic circulation patterns in GB, effects of salinity gradients can be disregarded in the modelling.
- However, it is important to remember that salinity has a great influence on the kinetic reactions of substances that characterize water quality. Therefore, although a model of hydrodynamic circulation in GB does not consider salinity gradients, it is important to include the transport of salinity in the analysis of water quality parameters.

\section{REFERENCES}

AMADOR, E. S. Baía de Guanabara e ecossistemas periféricos: homem e natureza. Rio de Janeiro: E. S. Amador, 1997.

ANDRIONI, L. L. Resposta da Baía de Guanabara a eventos extremos. 2013. 58 p. Dissertação (Mestrado Engenharia Civil). Universidade Federal do Rio de Janeiro, Rio de Janeiro, 2013. Retrieved from: $<$ http://www.pec.coppe.ufrj.br/pt/dissertacoes-de-mestrado/378msc-pt-2013/4218-leo-de-lacerda-andrioni> . Access on: 24 mar. 2017.

BARROS, M. L. C.; ROSMAN, P. C. C. A study on fish eggs and larvae drifting in the jirau reservoir, Brazilian Amazon. Journal of the Brazilian Society of Mechanical Sciences and Engineering, v. 40, n. 2, p. 62, 2018. http://dx.doi.org/10.1007/s40430-017-0951-1.

BÉRGAMO, A. L. Características hidrográficas, da circulação e dos transportes de volume e salinidade na Baía de Guanabara (RJ): variações sazonais e moduladas pela maré. 2006. 200 f. Tese (Doutorado em Oceanografia Física). Instituto Oceanográfico, Universidade de São Paulo, São Paulo, 2006. Retrieved from: < http://www.teses. usp.br/teses/disponiveis/21/21132/tde-22052007-161032/pt-br. php>. Access on: 14 jan. 2018.

CARVALHO, J. L. B. Modelagem e análise do lançamento de efluentes através de emissários submarinos. 2003. 190 f. Tese (Doutorado) - Universidade Federal do Rio de Janeiro, Rio de Janeiro, 2003. Retrieved from: $<$ http://www.teses.oceanica.ufrj.br/pdfs/2003_doutorado_joao_ luiz_baptista_de_carvalho.pdf>. Access on: 9 feb. 2017.

COELHO, V. M. B. Baía de Guanabara: uma história de agressão ambiental. Rio de Janeiro: Casa da Palavra, 2007.

COPPE - INSTITUTO ABERTO LUIZ COIMBRA DE PÓSGRADUAÇÃO E PESQUISA DE ENGENHARIA. SISBAHIA - Sistema Base de Hidrodinâmica Ambiental. Fundação COPPETEC/ UFRJ, 2019. Retrieved from: < http://www.sisbahia.coppe.ufrj. br>. Access on: 02 Jun. 2018.

COPPETEC - FUNDAÇÃO COORDENAÇÃO DE PROJETOS, PESQUISAS E ESTUDOS TECNOLÓGICOS. IVIG16861 - Termo de cooperaşão técnica e financeira $n^{\circ}$ 001/2012-SEP/PR, posteriormente SNP/MT. Rio de Janeiro, 2012.

COPPETEC - FUNDAÇÃO COORDENAÇÃO DE PROJETOS, PESQUISAS E ESTUDOS TECNOLÓGICOS. Modelagem de processos sedimentológicos na Baía de Guanabara, com foco na região do Canal do Mangue e Porto do Rio de Janeiro - RJ. Rio de Janeiro, 2015. 
COPPETEC-FUNDAÇÃO COORDENAÇÃO DE PROJETOS, PESQUISAS E ESTUDOS TECNOLÓGICOS. Modelagem de processos sedimentológicos no complexo portuário de Niterói e São Gonçalo - Baía de Guanabara. Rio de Janeiro, 2016.

CUNHA, C. L. N.; CORRÊA, G. P.; ROSMAN, P. C. C. A coupled model of hydrodynamics circulation and water quality applied to the Rio Verde reservoir, Brazil. Revista Ambiente \& Água, v. 13, n. 6, p. e2244, 2018. http://dx.doi.org/10.4136/ambi-agua.2244.

DAHER, V. B.; NOGUEIRA, I. C.; TEIXEIRA, G. L. G.; RIBEIRO, C. E. P.; ROSMAN, P. C. C. Análise das estimativas de maré meteorológica pelo modelo oceânico global HYCOM/ NCODA na região ao Largo Da Baía Da Ilha Grande - RJ. Anais Hidrográficos, v. 73, p. 113-124, 2016. Retrieved from: <https:// www.marinha.mil.br/dhn/sites/www.marinha.mil.br.dhn/files/ anais/ah_2016.pdf>. Access on: 14 May 2018.

DEAN, R. G.; DALRYMPLE, R. A. Coastal processes with engineering applications. Cambridge: Cambridge University, 2001. http://dx.doi. org/10.1017/CBO9780511754500.

DYER, K. R. Estuaries: a physical introduction. 2nd ed. England: John Wiley \& Sons Ltd., 1997.

ECMWF - European Centre for Medium-Range Weather Forecasts. ERA interim daily. 2017. Retrieved from: < https://apps.ecmwf. int $/$ datasets $/$ data $/$ interim-full-daily $/$ levtype $=s f c>$. Access on 1 jun. 2017.

FEITOSA, R. C.; ROSMAN, P. C. C.; BLENINGER, T.; WASSERMAN, J. C. Coupling bacterial decay and hydrodynamic models for sewage outfall simulation. Journal of Applied Water Engineering and Research, v. 1, n. 2, p. 137-147, 2013. http://dx.doi. org/10.1080/23249676.2013.878882.

GUIMARÃES, G. P.; SIGNORI, C. N.; REGO, B. C., et al. Pesquisas ecológicas de longa duração (PELD) - Guanabara: perfilagem de fatores físicos, físico-químicos e químicos em três estações na Baia de Guanabara. Gramado, 2011. Retrieved from: <http://www.peldguanabara. lncc.br/pdf/producao_pdf_49.pdf>. Access on: 15 jan. 2018.

KALIL, A. F. D. Contribuições ao estudo de nivel médio do mar do Rio de Janeiro. 1999. 104 f. Dissertação (Mestrado em Engenharia Oceânica) - Universidade Federal do Rio de Janeiro, Rio de Janeiro, 1999. Retrieved from: <http://www.teses.oceanica.ufrj.br/ pdfs/1999_mestrado_afonse_kalil.pdf>. Access on: 10 mar. 2017.

KAUFMANN, C. L. G. Estudo bidrodinâmico e de qualidade de água após revitalização da circulação do Canal do Fundão, Baía de GuanabaraRJ. 2009. 150 p. Dissertação (Mestrado em Engenharia Oceânica) - Universidade Federal do Rio de Janeiro, Rio de Janeiro, 2009. Retrieved from: < http://www.teses.oceanica.ufrj.br/pdfs/2009_ mestrado_clarisse_kaufmann.pdf>. Access on: 2 feb. 2017.

LABH2O - Laboratório de Hidrologia. Estudos hidrológicos da Bacia Contribuinte à Baía de Guanabara - Relatório interno. Rio de Janeiro: Universidade Federal do Rio de Janeiro, 2016.
MALTA, F. S. Estudo de correntes de maré do complexo estuarino da Baía de Guanabara - RJ. 2005. 132 f. Dissertação (Mestrado em Engenharia Oceânica) - Universidade Federal do Rio de Janeiro, Rio de Janeiro, 2005. Retrieved from: < http:/ / www.teses.oceanica. ufrj.br/pdfs/2005_mestrado_fernanda_siqueira_malta.pdf $>$. Access on: 10 feb. 2017.

MELO FILHO, E. Maré meteorológica na costa brasileira. 2017. 328 f. Tese (Professor Titular) - Universidade Federal de Rio Grande, Rio Grande, 2017. Retrieved from: <https://sistemas.furg.br/ sistemas/sab/arquivos/conteudo_digital/000008808.pdf > . Access on: 23 jan. 2018.

MIRANDA, L. B.; ANDUTTA, F. P.; KJERFVE, B.; CASTRO FILHO, B. M. Fundamentals of estuarine physical oceanography. Singapore: Springer Singapore, 2017. (Ocean Engineering \& Oceanography, v. 8). Retrieved from: <http://link.springer.com/10.1007/978981-10-3041-3>. Access on: 10 Mar. 2018.

PEIXOTO, R.; ROSMAN, P. C. C.; VINZON, S. B. A morphodynamic model for cohesive sediments transport. Revista Brasileira de Recursos Hídricos, v. 22, p. e57, 2017. http://dx.doi.org/10.1590/23180331.0217170066 .

PEREIRA, T. R. A. Impacto da descarga de efluentes sanitários dos rios sobre a qualidade das águas da Baía de Guanabara. 2017. 175 f. Dissertação (Mestrado) - Universidade Federal Fluminense, Rio de Janeiro, 2017.

PERHI - Plano Estadual de Recursos Hídricos. Estudos hidrológicos e vazões extremas. Rio de Janeiro: Fundação COPPETEC, 2014. Retrieved from: <http://www.hidro.ufrj.br/perhi/documentos/ PDF-R3-A-RT-1/R3A-RT-1-REV-02.pdf>. Access on: 6 sep. 2017.

PSAM - Programa de Saneamento Ambiental. Caracterização e diagnóstico: caracterização, indicadores e diagnóstico dos sistemas de abastecimento de água e de esgotamento sanitário regional. Rio de Janeiro: Secretaria de Meio Ambiente, 2014. (Estudos Regionais da Baixada Fluminense). Retrieved from: <https://pmsGBuanabara.wordpress. com/ersb/>. Access on: 10 may 2018.

ROSMAN, P. C. C. Referência técnica do SisBaHiA. 2018. Retrieved from: $<$ http://www.sisbahia.coppe.ufrj.br/SisBAHIA_RefTec_V9d_. pdf $>$. Access on: 5 mar. 2018.

ROVERSI, F.; ROSMAN, P.; HARARI, J. Análise das trajetórias das águas continentais afluentes ao sistema estuarino de santos. Revista Brasileira de Recursos Hídricos, v. 21, n. 1, p. 242-250, 2016 a. http://dx.doi.org/10.21168/rbrh.v21n1.p242-250.

ROVERSI, F.; ROSMAN, P.; HARARI, J. Water renewal analysis of the Santos Estuarine System using computational modeling. Revista Ambiente \& Água, v. 11, n. 3, p. 566-585, 2016b. http:// dx.doi.org/10.4136/ambi-agua.1770.

SAMPAIO, M. Estudo de circulação bidrodinâmica 3D e trocas de massas d'água da Baía de Guanabara - RJ. 2003. 213 f. Dissertação (Mestrado em Engenharia Civil) - Universidade Federal do Rio de Janeiro, 
Rio de Janeiro, 2003. Retrieved from: <http://www.pec.coppe. ufrj.br/en/dissertacoes-de-mestrado/103-msc-pt-2003/1830marcelle-sampaio >. Access on: 15 feb. 2017.

SANTOS, S. J. C. Determinação do estado trófico a partir da aplicação dos indices O'Boyle e TRIX nos compartimentos da Baía de Guanabara, RJ. 2015. 101 f. Dissertação (Mestrado) - Universidade Federal Fluminense, Niterói, 2015. Retrieved from: < https:/ /app.uff.br/ riuff/handle/1/1642>. Access on: 28 feb. 2018.

SAWAKUCHI, H. O.; NEU, V.; WARD, N. D.; BARROS, M. L. C.; VALERIO, A. M.; GAGNE-MAYNARD, W.; CUNHA, A. C.; LESS, D. F. S.; DINIZ, J. E. M.; BRITO, D. C.; KRUSCHE, A. V.; RICHEY, J. E. Carbon dioxide emissions along the lower Amazon River. Frontiers in Marine Science, v. 4, p. 76, 2017. http:/ / dx.doi.org/10.3389/fmars.2017.00076.

SILVA, R. A. G.; ROSMAN, P. C. C. Hydro-sedimentary viability of a projected tidal inlet on the western side of Araruama Lagoon-
RJ. Revista Brasileira de Recursos Hídricos, v. 21, n. 1, p. 25-35, 2016. http://dx.doi.org/10.21168/rbrh.v21n1.p25-35.

\section{Authors contributions}

Veronica Silveira de Andrade: Contribution in the paper conception, literature review, development of computational modeling, preparation of graphs and maps, interpretation and discussion of results, and writing and formatting of the paper.

Paulo Cesar Colonna Rosman: Contribution in the paper conception, support in the development of the models, discussion of the results, review and editing.

José Paulo Soares de Azevedo: Discussion of the results, review and editing. 


\section{ANNEX I}

Comparison of patterns of hydrodynamic circulation for models without (above) and with (below) baroclinic pressure gradient. Note that the velocities scale is the same on all maps, evidencing the similarity of the patterns of circulation.

\section{Velocity $(\mathrm{m} / \mathrm{s})$}

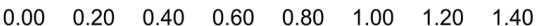

Model without baroclinic pressure gradient
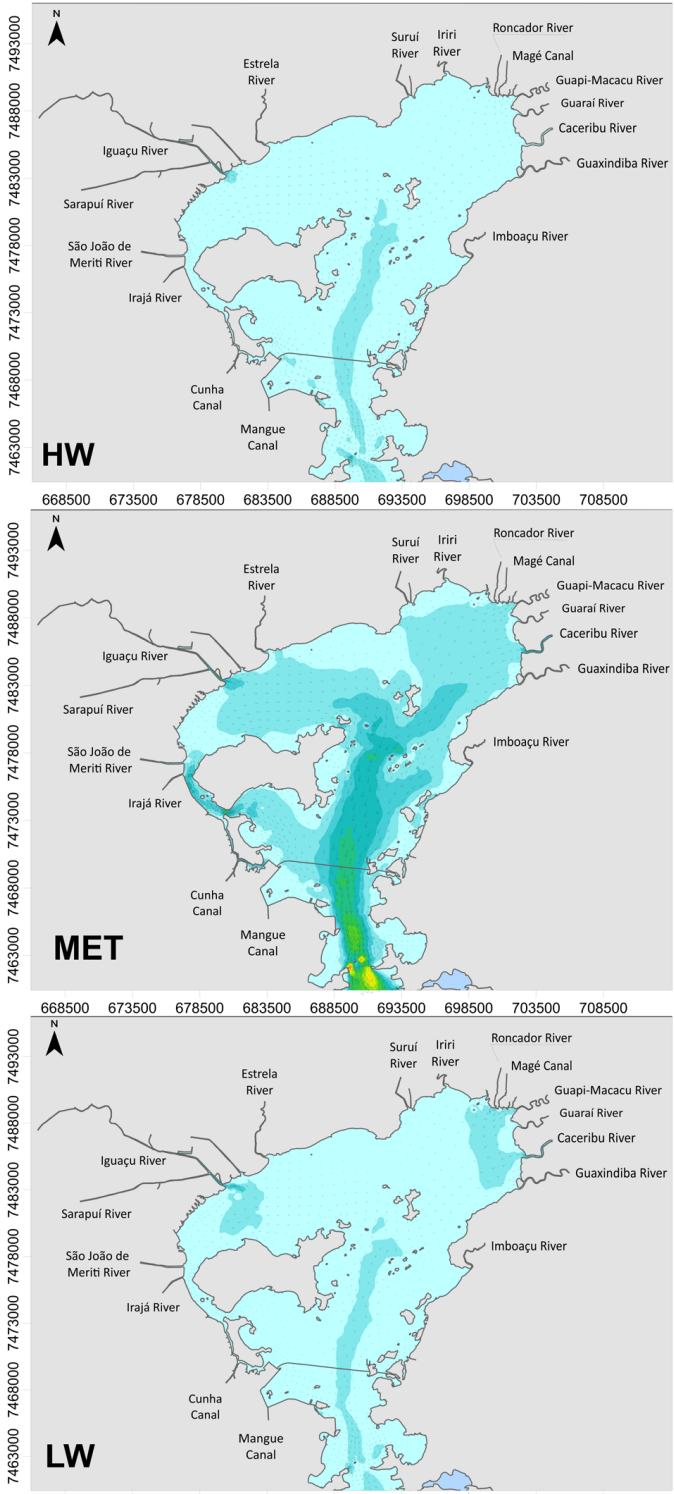

$\begin{array}{lllllllll}668500 & 673500 & 678500 & 683500 & 688500 & 693500 & 698500 & 703500 & 708500\end{array}$

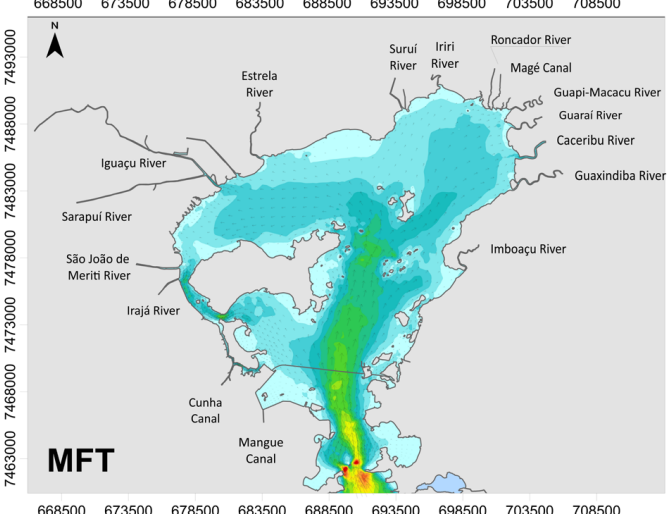

\section{Model with baroclinic pressure gradient}

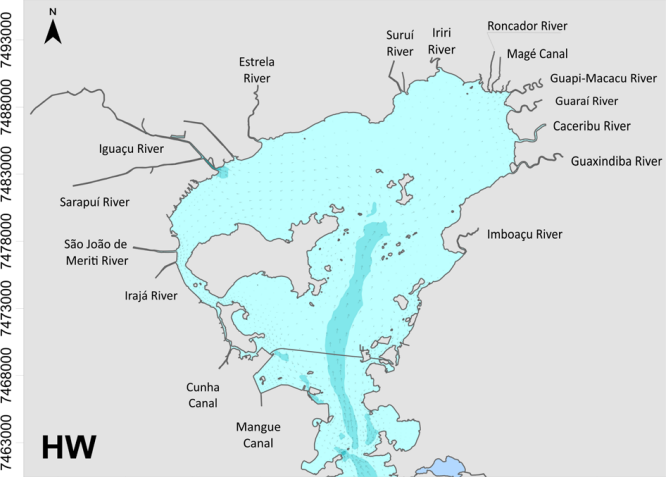

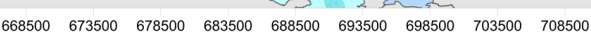

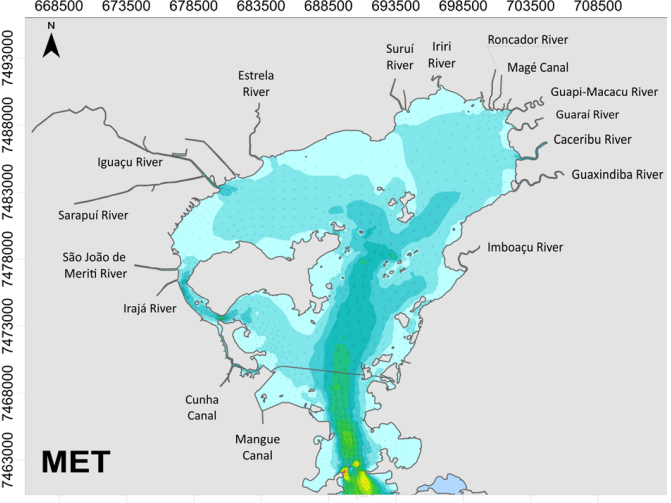

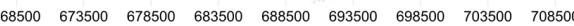
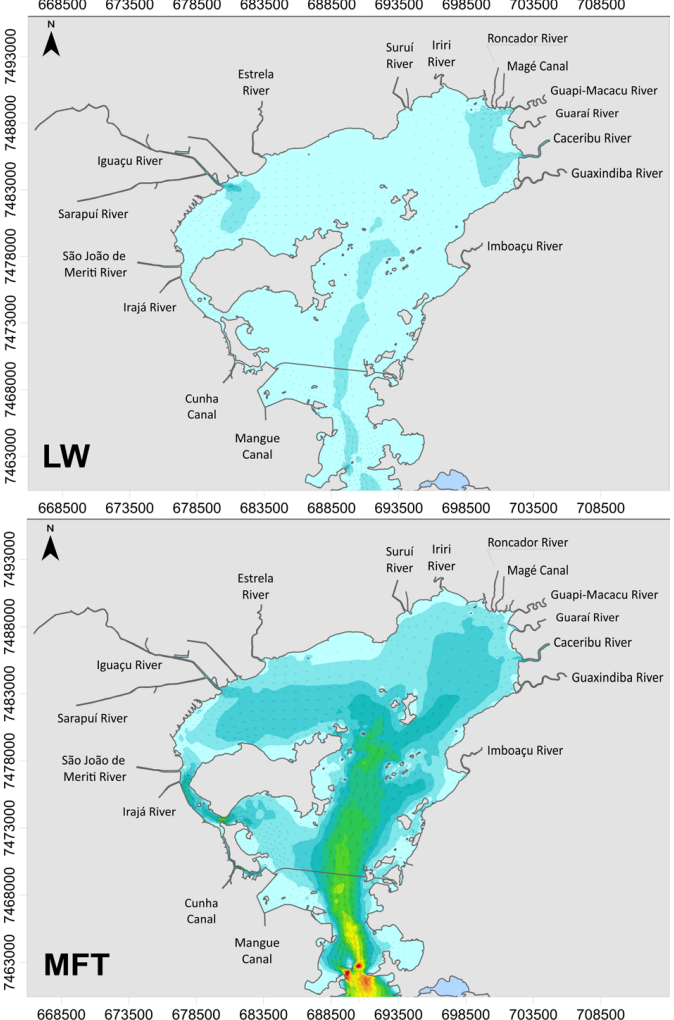

Coordinate System: WGS84; Projection: UTM, Zone 23S / Map drawn in Google Earth Pro and produced in Surfer 14 